\title{
Environmental Wisdom of Lampung Warahan Oral Literature in Literature Ecology Perspective
}

\author{
Kahfie Nazaruddin \\ Department of Language and Arts \\ Education \\ Lampung University \\ Lampung, Indonesia \\ kahfie.nazaruddin@fkip.unila.ac.id
}

\author{
Rian Andri Prasetya \\ Department of Language and Arts \\ Education \\ Lampung University \\ Lampung, Indonesia \\ rian.andri@fkip.unila.ac.id
}

\author{
Ali Mustofa \\ Department of Language and Arts \\ Education \\ Lampung University \\ Lampung, Indonesia \\ ali.mustofa@fkip.unila.ac.id
}

\author{
Ryzal Perdana \\ Educational Science \\ Lampung University \\ Lampung, Indonesia \\ ryzalperdana@@fkip.unila.ac.id
}

\begin{abstract}
The character of caring for the environment is a character that must be possessed by every human being. This character has existed since ancient times. This is because our ancestors were humans who cared about the environment. This study aims to describe the environmental wisdom of the Lampung people in the oral literature of Lampung Wareham. This study used the descriptive qualitative method. The result of this research is the concept of environmental wisdom owned by the people of Lampung.
\end{abstract}

Keywords-Environmental Wisdom, Oral Literature, Lampung, Warahan, Ecology

\section{INTRODUCTION}

Pollution and environmental damage are global issues that until now continue to be a major concern. Wahana Lingkungan Indonesia (WALHI) released the Intergovernmental Science-Policy Platform on Biodiversity and Ecosystem Services (IPBES) report on damage to the world's current ecosystems in early May 2019. IPBES reports that as many as one million species have gone extinct in the past 50 years due to human activity. As a result of environmental pollution is also felt by the people of Lampung. The people of Lampung participate in pollution and environmental damage that occurs. Based on news from the beritasatu.com website in February 2018 WALHI reported forest damage in Lampung reached $65 \%$ and this was caused by a lack of supervision. At the end of 2019 in Lampung, there was a forest fire that hit Way Kambas national park and Bukit Barisan National Park. The result of the damage is as many as 22 streams in Lampung - especially in Bandarlampung - polluted so that the supply of clean water becomes reduced. Recently the problem of garbage caused flood disasters in various regions in Lampung Province.

The low sense of care and awareness of the people of Lampung towards the environment is suspected to be the cause of various environmental pollution and disasters that occurred in Lampung Province recently. Whereas the values about the environmental wisdom of Lampung indigenous peoples are widely contained in various oral literature Lampung. These oral literary forms include warahan (storytelling) proverbs, puzzles, mantras, and poetry [2]-[4]. The spread of Lampung oral literature is carried out hereditarily in various activities and atmospheres, namely when relaxing; doing handicrafts (weaving tapis, embroidery, making webbing); working in gardens, fields, and rice fields; welcoming ceremonies of traditional guests; ceremonies of giving juluk and adok; young events, cangget, and ducks[5].

Oral literature warahan used to be often done by ethnic Lampung with storytelling. Storytelling activities are carried out by Storytellers during entertainment events in the village. However, currently, storytelling/storytelling activities are rarely done due to the shifting lifestyle of Lampung people from farming/field communities to business communities. This led to increasingly rare storytellers being found [6]. Though storytelling activities are one effective way to shape a person's character [7],[8].

Characters that can be grown through storytelling activities include the character of caring about the environment. The character is very appropriately 
developed through storytelling activities on the Lampung ethnic group because the fairy tales told in Lampung oral literature reveal and present the typical environment of the Lampung area. Based on the results of the study 15 stories are often told in the indigenous people of Lampung Pubiyan. The story is Katca sai Setia 'Loyal Friends', Ngisik Anak Buha 'Keeping a Crocodile Cub', Teguh rik Katjongni 'Firm and His Wife, Raja jama Iwa 'King with Fish' , Raja Ngebun Ketila 'King of Gardening Cassava', Bebai Tuha Penunggu Huma 'The Garden-Supporting Grandmother ', Raja Nganak Pitu 'Seven-Armed King', Si Bikkuk rik Si Lurus 'The Hunchback and the Straight', Kiyai Ratu Di Jambi 'Kiai Ratu Di Jambi', Beruk jama Hantipa 'Dredging with Turtles', Kera Rasah rik Beruk Jalu 'Kera Rasah with Beruk Jalu', Asal Mula Tiuh Kedamaian 'The Origin of the Kedamaian Village, Asal Mula Tiuh Kurungan Nyawa ' The Beginning Kurungan Nyawa Village', Terjadini Gunung Kelutum 'Occurrence of Gunung Kelutum', Asal Mula Tiuh Bumi Agung 'Origin of The Beginning Bumi Agung Village'[6].

Early perspectives based on the titles of these stories have revealed many relationships between humans and their environment. Thus, to be able to regrow the character of environmental care of the people of Lampung need to be done a study that reveals environmental wisdom in the people of Lampung itself. Theories that can be used to uncover environmental wisdom in literature uses literary ecology theory. The theory used contains about how environmental wisdom is formed and how the values contained form the basis of environmental wisdom. The results of the research can be used as a basis to develop a form of learning based on environmental wisdom by instilling environmental character in learners.

\section{LITERATURE REVIEW}

\section{A. Literature Ecology}

Literary ecocriticism is a critical theory in the cutting-edge approach of literature. The multidisciplinary nature of literary ecocriticism (ecology and literature) requires the presence, togetherness, and unity of various relevant theories and concerts on the problems of literary and environmental studies, among them critical theory, literary criticism, cultural theory, and environmental ethics theory (ecology) [9].

Ecocriticism can help define, explore, and even solve ecological problems in a broader sense. In its function as a medium of representation of people's attitudes, views, and responses to the surrounding environment, literature has the potential to express ideas about the environment, including the values of environmental wisdom. This is very reasonable considering that literature grows, develops, and is sourced from the community environment and the natural environment (ecological) [10].
To be said ecology literature, Lawrence Buell mentions several criteria, namely (1) the non-human environment is present not only as a frame but as a presence that shows that human history is implied in natural history; (2) Human interests are not understood as the only legitimate interests; (3) Human accountability to the environment is part of the ethical orientation of the text, and (4) some notions of the environment are as a process not as a constant understanding or a gift least implied in the text [11].

\section{B. Environmental Wisdom}

Environmental wisdom departs from the model of the study of ethics. Ethics speaks of moral values and principles embraced by a particular society as guidelines and criteria for behaving as human beings. In general, the value system, maintained as a good habit of life, is passed down and inherited through religion and culture, which is considered the main source of moral norms and values. [12].

Ethics requires means and media expression. The means of ethical expression in the form of language, although non-language aspects are also taken into account. The medium of expression can be tangible (works) literature. Ethics are expressed through the language of various forms. One of the manifestations is the ethics of an environment or (value) environmental wisdom. Environmental wisdom is an awareness to be part of nature to create a unity of harmony [13].

In substance, each notion of local wisdom has similarities and dissociation. The religiousness of the understanding can be separated into an understanding that emphasizes, highlights, prioritizes, or prioritizes aspects (i) of the sincere; (ii) form or form; (iii) characteristics or characteristics; (iv) function; (v) patterns of inheritance and forms of expression; as well as (vi) results [14].

From a number of these aspects can (i) be formulated the understanding of local wisdom (read: environmental wisdom) as a device of knowledge and practice resulting from intensive human reflection on nature and its past experiences to bring ethics, values, and principles that are useful practical to solve life problems and have positive implications for the maintenance and preservation of the environment; (ii) it is firmly known that local wisdom is closely related to man's relationship with his environment or nature; So that it can (iii) be clearly understood that environmental problems stem from the irregularity of the relationship between humans and their environment and this is rooted in human behavior that does not make local wisdom as the ethical basis of his behavior.

Environmental wisdom is a form of moral principles in the form of respect for nature, the attitude of responsibility to nature, cosmic solidarity, the principle of compassion and concern for nature, the principle of not harming nature, the principle of simple life, and in harmony with nature; the principle of 
justice; principles of democracy; The principle of moral integrity [15]-[17].

\section{THE STUDY}

This research is qualitative descriptive. Qualitative research is research that intends to understand phenomena about what is experienced by the subject of research e.g., behavior, perception, motivation, action, etc. holistically and through the description in the form of words and language, in a special context that is natural and by utilizing various natural methods [18]. The approach used to conduct this research is an ecocriticism approach. Literature has always been related to humans, one of the components in it is the environment. Literature is a mirror of the state of the environment [19].

Data analysis begins by quickly reading all the folklore contained in the book Oral Literature Lampung Dialect Pubiyan [6]. Then all the folklore in the book is marked as a selected data source. The readings are then grouped with considerations: (1) folklore that takes the environment as a background of place and time, (2) folklore-themed environment with certain symbols, namely trees and water, (3) folklore involving the main character in conflicts around the environment. After that, using the basic principles of Ecocriticism, the short stories are read over and over again to gain a deep understanding. Ecocriticism theory is obtained mainly from the fruit of thought that argues that environmental wisdom is tangible moral principles in the form of respect for nature, the attitude of responsibility to nature ( moral responsibility for nature), cosmic solidarity (cosmic solidarity), the principle of compassion and concern for nature ( caring for nature), the principle of not harming nature ( no harm), the principle of living simply and in harmony with nature; principles of justice; principles of democracy; and the principle of moral integrity [15][17].

In summary, the procedure for this research can be seen in the image below.

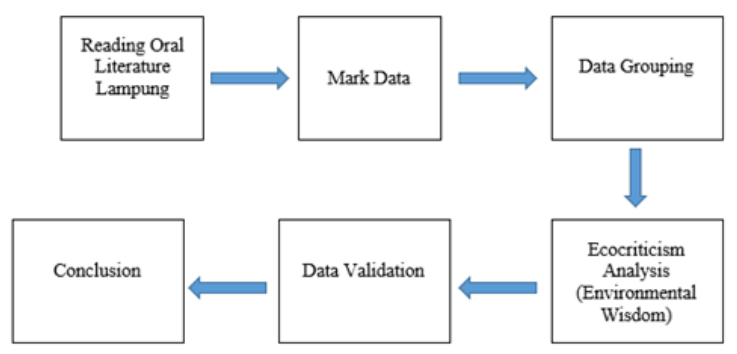

Fig. 1. Research procedure

\section{FINDINGS}

Data collection produced 19 descriptive units regarding the value of environmental wisdom in Lampung warahan oral literature. The data describe the five values of environmental wisdom contained in Lampung oral literature. The value of environmental wisdom is obtained from 14 Lampung oral literature (warahan) that developed in the Lampung Pubiyan area. The value of environmental wisdom can be seen in the table below.

TABLE I. DISTRIBUTION OF ENVIRONMENTAL WISDOM VALUES IN WARAHAN

\begin{tabular}{|c|c|c|c|}
\hline No & Story Title & Values of Environmental Wisdom & Sum \\
\hline \multirow[t]{9}{*}{1} & Katca sai Setia / Kawan yang Setia & $\begin{array}{l}\text { (1) Moral responsibility for nature } \\
\text { (2) cosmic solidarity }\end{array}$ & 2 \\
\hline & $\begin{array}{l}\text { Cerita Ngisik Anak Buha / Cerita Memelihara Anak } \\
\text { Buaya }\end{array}$ & $\begin{array}{l}\text { (1) caring for nature } \\
\text { (2) The Principle of Not Disturbing Natural Life }\end{array}$ & 2 \\
\hline & Raja Jama Iwa / Raja dengan Ikan & $\begin{array}{l}\text { (1) The Principle of Not Disturbing Natural Life } \\
\text { (2) The Principle of Compassion and Concern for } \\
\text { Nature }\end{array}$ & 2 \\
\hline & $\begin{array}{l}\text { Cerita Kera Rasah rik Beruk Jalu / Cerita Kera } \\
\text { Rasah dengan Beru Jalu }\end{array}$ & (1) Solidarity towards Nature & 1 \\
\hline & Raja Ngebun Ketila 'Raja Berkebun Ketela' & (1) respect for nature & 1 \\
\hline & $\begin{array}{l}\text { Bebai Tuba Penunggu Huma 'Si Nenek Penunggu } \\
\text { Kebun' }\end{array}$ & (1) moral responsibility for nature & 1 \\
\hline & Raja Nganak Pitu /'Raja Berputri Tojuh' & (1) cosmic solidarity & 1 \\
\hline & Si Bikkuk rik Si Lurus /'Si Bengkok dan Si Lurus' & (1) moral responsibility for nature & 1 \\
\hline & Kiyai Ratu di Jambi / Kiai Ratu di Jambi & $\begin{array}{l}\text { (1) caring for nature) } \\
\text { (2) cosmic solidarity }\end{array}$ & 2 \\
\hline
\end{tabular}




\begin{tabular}{|l|l|l|c|}
\hline & Beruk jama Hantipa/ Beruk dengan Kura-kura & $\begin{array}{l}\text { (1) caring for nature } \\
\text { (2) cosmic solidarity } \\
\text { (3) moral responsibility for nature }\end{array}$ & 3 \\
\hline $\begin{array}{l}\text { Kera Rasah rik Beruk Jalu /Kera Rasah dengan } \\
\text { Beruk Jalu }\end{array}$ & $\begin{array}{l}\text { (1) cosmic solidarity } \\
\text { Kedamaian Tiuh Kedamaian/Asal Mula Kampung }\end{array}$ & (1) moral responsibility for nature & 1 \\
\hline $\begin{array}{l}\text { Asal Mula Tiuh Kurungan Nyawa 'Asal Mula } \\
\text { Kampung Kurungan Nyawa' }\end{array}$ & (1) caring for nature & 1 \\
\hline $\begin{array}{l}\text { Terjadini Gunung Kelutum 'Terjadinya Gunung } \\
\text { Kelutum' }\end{array}$ & (1) cosmic solidarity & 1 \\
\hline
\end{tabular}

The table above shows that each oral literature of Lampung has a value of environmental wisdom with varying amounts. There is no oral literature Lampung that does not have the value of environmental wisdom. There is some oral literature Lampung that has more than one value of environmental wisdom. Lampung oral literature that has the most value of environmental wisdom is found in folklore titled Beruk Jama Hantipal "Beruk with Turtles".

Oral literature in the form of folklore has been passed down through generations by the ancestors of the Lampung people. Thus, since ancient times the people of Lampung already have the values of environmental wisdom and treat the natural environment as an inseparable entity. This is evident from the values of environmental wisdom that appear in Lampung's oral literature.

The value of environmental wisdom that appears in Lampung oral literature consists of respect for nature, moral responsibility towards nature, solidarity with nature, case of affection and concern for nature, and does not interfere with natural life. The following is a table of distribution values of environmental wisdom in Lampung oral literature.

TABLE II. FREQUENCY DISTRIBUTION OF STUDENTS' CRITICAL AND CREATIVE THINKING (CCT) SKILLS

\begin{tabular}{|c|c|c|c|}
\hline No. & Values of Environmental Wisdom & Title & Sum \\
\hline \multirow[t]{3}{*}{1} & \multirow[t]{3}{*}{ Respect For Nature } & Raja Ngebun Ketila 'Raja Berkebun Ketela' & \multirow[t]{3}{*}{3} \\
\hline & & Bebai Tuba Penunggu Нuma 'Si Nenek Penunggu Kebun' & \\
\hline & & Si Bikkuk rik Si Lurus 'Si Bengkok dan Si Lurus' & \\
\hline \multirow[t]{4}{*}{2} & \multirow[t]{4}{*}{ Moral Responsibility For Nature } & Katca sai Setia / Kawan yang Setia & \multirow[t]{4}{*}{4} \\
\hline & & Cerita Ngisik Anak Buha / Cerita Memelihara Anak Buaya & \\
\hline & & Beruk jama Hantipa/ Beruk dengan Kura-kura & \\
\hline & & Asal Mula Tiuh Kedamaian/Asal Mula Kampung Kedamaian & \\
\hline \multirow[t]{6}{*}{3} & \multirow[t]{6}{*}{ Cosmic solidarity } & Katca sai Setia / Kawan yang Setia & \multirow[t]{6}{*}{6} \\
\hline & & $\begin{array}{l}\text { Cerita Kera Rasah rik Beruk Jalu / Cerita Kera Rasah dengan } \\
\text { Beru Jalu }\end{array}$ & \\
\hline & & Raja Nganak Pitu 'Raja Berputri Tujuh' & \\
\hline & & Kiyai Ratu di Jambi / Kiai Ratu di Jambi & \\
\hline & & Kera Rasah rik Beruk Jalu /Kera Rasah dengan Beruk Jalu & \\
\hline & & Tarjadini Gunung Kelutum 'Te1jadinya Gunung Kelutum' & \\
\hline \multirow[t]{4}{*}{4} & \multirow[t]{4}{*}{ Caring For Nature } & Cerita Ngisik Anak Buha / Cerita Memelihara Anak Buaya & \multirow[t]{4}{*}{4} \\
\hline & & Raja Jama Iwa / Raja dengan Ikan & \\
\hline & & Kiyai Ratu di Jambi / Kiai Ratu di Jambi & \\
\hline & & $\begin{array}{l}\text { Asal Mula Tiuh Kurungan Nyawa 'Asal Mula Kampung } \\
\text { Kurungan Nyawa' }\end{array}$ & \\
\hline 5 & $\begin{array}{l}\text { The Principle Of Not Harming } \\
\text { Nature }\end{array}$ & Cerita Ngisik Anak Buha / Cerita Memelihara Anak Buaya & 2 \\
\hline
\end{tabular}

Based on the table, it is seen that the value of environmental wisdom that is most widely revealed is the value of solidarity with nature. Solidarity with nature contained in Warahanin the form of (1) recognition of equal and equal standing with nature and with other living beings in this nature; (2) The attitude of feeling what is felt by nature; (3) efforts to save nature, prevent man from damaging and polluting nature and the whole of life in it; and (4) efforts to harmonize human behavior with ecosystems.

\section{DISCUSSION}

The value of environmental wisdom in Lampung oral literature in the form of respect for nature is found in several-folklore, namely Raja Ngebun Ketila 'King of Gardening Ketela', Bebai Tuba Penunggu Huma 'The Grandmother of the GardenGuisher', and Si Bikkuk rik Si Lurus 'The Crooked and The Straight'. Forms of respect for nature include (1) the ability to respect nature, (2) the awareness that nature has value in itself, (3) the realization that nature has the right to 
be respected, (4) the awareness that nature has integrity, and (5) the appreciation of nature for being, living, growing, and developing naturally following the purpose of its creation.

Environmental wisdom in the form of responsibility to nature is contained in several stories, namely Katca sai Setia / Loyal Friends, Ngisik Story of Buha Children / Stories of Nurturing Crocodile Children, Beruk jama Hantipa/ Beruk with Turtles, and The Origin of Peace/ Origin ofKampung Damai. Moral responsibility to nature is manifested in the form of reminding, forbidding, and punishing anyone who intentionally or unintentionally or unnecessarily harms the existence of nature.

Environmental wisdom in the form of an attitude of solidarity towards nature is found in Lampung's oral literature in the form of stories. Solidarity with nature is found in stories titled Katca sai Setia / Loyal Friends, Stories of Kera Rasah rik Beruk Jalu / Stories of Rasah Apes with Beru Jalu, King Nganak Pitu 'Seven-White King', Kiyai Ratu in Jambi / Kiai Ratu in Jambi,and The Kelutum 'become Mount Kelutum'. A soldier's embrace of nature manifests in (1) the recognition of equal and equal standing with nature and with other living things in this realm; (2) The attitude of feeling what is felt by nature; (3) efforts to save nature, prevent man from damaging and polluting nature and the whole of life in it; and (4) efforts to harmonize human behavior with ecosystems.

The next environmental wisdom value is compassion and concern for nature. This value appears in some of Lampung's oral literature in the form of stories (warahan). The value of affection and concern for nature is found in the story titled Ngisik Anak Buha Story / Story of Keeping Crocodile Children, King Jama Iwa / King with Fish, Kiyai Ratu in Jambi / Kiai Ratu in Jambi, and Origin of Life Confinement 'Origin of Life Confinement Village'. Compassion and concern for nature arise from the fact that as fellow members of the ecological community, all living things have the right to be protected, nurtured, not harmed, and cared for. This principle is a moral principle one way, towards the other, without expecting anything in return.

The value of environmental wisdom that was last found in Lampung oral literature is that it does not interfere with natural life. Lampung oral-literary stories containing these values are contained in stories titled Ngisik Anak Buha Story / Story of Keeping Crocodile Children, and Raja Jama Iwa / King with Fish. The attitude of not disturbing the life of nature contained in (1) consciousness does not harm nature unnecessarily, (2) ability does not threaten the existence of living things in the universe, (3) the participation and perception of obligations do not harm nature in the norm, and (3) the distribution of nature in an untouched state.

\section{CONCLUSION}

Lampung oral literature in the form of folklore that has been passed down through generations in the indigenous people of Lampung Pubiyan contains the values of environmental wisdom. The values of environmental wisdom contained in the 14 stories are the value of respect for nature, moral responsibility towards nature, solidarity with nature, case of affection and concern for nature, and do not interfere with natural life.

The values of environmental wisdom identified show that since ancient times the people of Lampung have been very concerned about nature and the environment. In addition, since ancient times the people of Lampung are also very dependent on nature so that they always maintain a harmonious relationship with nature and the environment.

For other researchers who are interested in exploring the value of environmental wisdom, Lampung people are advised to continue this research by studying Lampung oral literature in other forms such as pisaan, bebandung, pattun, predator, or stories (warahan)originating from other region in Lampung. This can be useful in mapping and exploring patterns of environmental wisdom in the people of Lampung and in the context of planting the character of environmental care in the next generation living in Lampung.

\section{ACKNOWLEDGMENT}

We want to thank all respondents for taking part in this study. We also thank the University of Lampung LPPM for funding this research.

\section{REFERENCES}

[1] WALHI, Memutus Impunitas Korporasi. 2019.

[2] D. Ratnaningsih, "Kajian Puisi: Piil Pesenggiri dalam Puisi." Universitas Muhammadiyah Kotabumi, 2019.

[3] H. Hasyimkan, E. Barnawi, and U. Hakim, "KAJIAN SYAIR PADA WARAHAN KLASIK TENTANG GAMOLAN INSTRUMEN MUSIK TRADISIONAL LAMPUNG," $J$. Warn., vol. 4, no. 1, pp. 11-22, 2020.

[4] R. Hidayatullah, B. Riadi, and G. E. Putrawan, "Transformasi Tradisi Lisan Lampung dalam Seni Pertunjukan: Perspektif Pendidikan dan Pewarisan Budaya," PROSIDING, p. 47, 2017.

[5] A. E. Sanusi, Sastra Lisan Lampung Dialek Abung. Bandarlampung: Bagian Proyek Penelitian dan Pembinaan Bahasa dan Sastra Indonesia dan Daerah, 1991.

[6] N. Udin, Sastra Lisan Lampung Dialek Pubiyan. Jakarta: Departemen Pendidikan dan Kebudayaan, 1998.

[7] Z. Habsari, "Dongeng sebagai pembentuk karakter anak," BIBLIOTIKA J. Kaji. Perpust. Dan Inf., vol. 1, no. 1, pp. 2129, 2017.

[8] J. Juanda, "Revitalisasi nilai dalam dongeng sebagai wahana pembentukan karakter anak usia dini," J. Pustaka Budaya, vol. 5, no. 2, pp. 11-18, 2018.

[9] G. Huggan and H. Tiffin, Postcolonial ecocriticism: Literature, animals, environment. Routledge, 2015.

[10] G. Garrad, The Oxford Handbook of Ecocriticism. Oxford: Oxford University Press, 2014. 
[11] L. Buell, "The Emergence of Environmental Criticism," in The Future of Environmental Criticism: Environmental Crisis and Literary Imagination, Malden: Blackwell, 2005.

[12] S. A. Keraf, Etika Lingkungan Hidup. Jakarta: Penerbit Buku Kompas, 2010.

[13] P. Amrih, Ilmu Kearifan Jawa. Pitoyo Amrih, 2008.

[14] S. Sukmawan, "MODEL-MODEL KAJIAN EKOKRITIK SASTRA," pp. 1-17.

[15] A. Naess, Ecology, community and lifestyle: outline of an ecosophy. Cambridge university press, 1990.
[16] P. Singer, Practical ethics. Cambridge university press, 2011.

[17] A. S. Keraf, Etika lingkungan hidup. Penerbit Buku Kompas, 2010

[18] L. J. Moleong, Metodologi penelitian kualitatif. PT Remaja Rosdakarya, 2021.

[19] S. Endraswara, Sastra ekologis: teori dan praktik pengkajian. Center for Academic Publishing Service, 2016. 